\title{
Urotensin II-Induced Increase in Myocardial Distensibility Is Modulated by Angiotensin II and Endothelin-1
}

\author{
A. P. FONTES-SOUSA, A. L. PIRES, V. F. MONTEIRO-CARDOSO, \\ A. F. LEITE-MOREIRA \\ Department of Physiology, Faculty of Medicine, University of Porto, Porto, Portugal
}

Received February 7, 2008

Accepted September 9, 2008

On-line November 4, 2008

\begin{abstract}
Summary
Endogenous regulators, such as angiotensin-II (AngII), endothelin-1 (ET-1) and urotensin-II (U-II) are released from various cell types and their plasma levels are elevated in several cardiovascular diseases. The present study evaluated a potential crosstalk between these systems by investigating if the myocardial effects of U-II are modulated by AngII or ET-1. Effects of U-II $\left(10^{-8}, 10^{-7}, 10^{-6} \mathrm{M}\right)$ were tested in rabbit papillary muscles in the absence and in the presence of losartan (selective $\mathrm{AT}_{1}$ receptor antagonist), PD-145065 (nonselective ET-1 receptors antagonist), losartan plus PD-145065, AngII or ET-1. U-II promoted concentration-dependent negative inotropic and lusitropic effects that were abolished in all experimental conditions. Also, U-II increased resting muscle length up to $1.008 \pm 0.002 L / L_{\max }$. Correcting it to its initial value resulted in a $19.5 \pm 3.5 \%$ decrease of resting tension, indicating increased muscle distensibility. This effect on muscle length was completely abolished in the presence of losartan and significantly attenuated by PD-145065 or losartan plus PD-145065. This effect was increased in the presence of AngII, resulting in a $27.5 \pm 3.9 \%$ decrease of resting tension, but was unaffected by the presence of ET-1. This study demonstrated an interaction of the U-II system with the AngII and ET-1 systems in terms of regulation of systolic and diastolic function.
\end{abstract}

\section{Key words}

Urotensin II • Angiotensin II • Endothelin-1 • Cardiac function • Myocardial distensibility

\section{Corresponding author}

Professor Adelino F. Leite-Moreira, Department of Physiology, Faculty of Medicine, Alameda Professor Hernâni Monteiro, 4200-319 Porto, Portugal. Fax: $+/ 351 / 22 / 551.36 .46$. E-mail: amoreira@med.up.pt

\section{Introduction}

Urotensin II (U-II) is a vasoactive cyclic peptide that was originally isolated from fish urophysis and has been cloned from humans (Coulouarn et al. 1998). U-II has been identified as the endogenous ligand for the orphan G protein-coupled receptor, GPR14 (U-II receptor, UT) (Ames et al. 1999, Douglas et al. 2002). Both U-II and its receptor are expressed in the mammalian cardiovascular system namely in the myocardium, vascular smooth muscle cells and endothelial cells (Johns et al. 2004, Egginger et al. 2006). Human U-II (hU-II) effectively constricts isolated arteries from non-human primates. The potency of vasoconstriction is of a greater magnitude than that of endothelin 1 (ET-1), making U-II the most potent mammalian vasoconstrictor (Ames et al. 1999).

Furthermore, U-II was reported to affect the process of cell growth in the heart. This peptide exerted mitogenic effects on vascular smooth muscle cells (Sauzeau et al. 2001, Watanabe et al. 2001a,b) and human endothelial cells (Shi et al. 2006), induced collagen and fibronectin synthesis by cardiac fibroblasts, and caused cardiomyocyte hypertrophy (Tzanidis et al. 2003, Johns et al. 2004, Russell 2004). Thereby, U-II contributes to ventricular remodeling and deterioration of systolic and diastolic function, similarly to what has been described for other vasoconstrictor peptides such as angiotensin-II (AngII) and ET-1 (Weber et al. 1994, Ito 1997).

Moreover, elevation of U-II in the plasma and hearts of patients with congestive heart failure has been observed, and these circulating levels were related to the 
functional class of the disease and correlated negatively with left ventricular ejection fraction (Douglas et al. 2002, Russell et al. 2003, Russell 2004, Gruson et al. 2006). U-II also correlated significantly with big-ET-1 and brain natriuretic peptide, suggesting that U-II could play a role in worsening the course of congestive heart failure and is associated with established markers of cardiovascular dysfunction (Gruson et al. 2006).

Unlike the well-known role of chronically elevated U-II levels in progression to cardiac fibrosis and ventricular remodeling, the acute diastolic effects of U-II remain less explored. We previously found that AngII (Leite-Moreira et al. 2006), ET-1 (Leite-Moreira et al. 2003, Brás-Silva et al. 2008) and U-II acutely increase myocardial distensibility. In the case of U-II this effect is mediated by UT receptor, NO and prostaglandins (Fontes-Sousa et al. 2007). The intracellular signaling of U-II and its interaction with other vasoconstrictors such as AngII and ET-1 are poorly understood, although is has been established that U-II shares some subcellular pathways and interacts with these vasoactive systems (Tasaki et al. 2004, Li et al. 2005, Wang et al. 2007). Although plausible, the crosstalk between U-II and AngII or ET-1 in the regulation of myocardial distensibility has not been studied yet. The main goal of the present study was therefore to test this hypothesis by investigating to what extent the myocardial effects of U-II are modulated by AngII or ET-1.

\section{Methods}

The investigation conforms to the Guide for the Care and Use of Laboratory Animals published by the US National Institutes of Health (NIH Publication $\mathrm{N}^{\circ}$ 85-23, Revised 1996).

\section{Experimental preparation}

Isometric and isotonic contractions were measured in papillary muscles isolated from the right ventricle of rabbits. Male New Zealand White rabbits (Oryctolagus cuniculus, 1.2-2.7 kg, $\mathrm{n}=32$ ) were anesthetized with intravenous sodium pentobarbital (25 mg. $\left.\mathrm{kg}^{-1}\right)$. A left thoracotomy was performed, and beating hearts were quickly excised and immersed in a modified Krebs-Ringer (KR) solution (composition in mM: $98 \mathrm{NaCl}, 4.7 \mathrm{KCl}, 2.4 \mathrm{MgSO}_{4}, 1.2 \mathrm{KH}_{2} \mathrm{PO}_{4}$, 4.5 glucose, $1.8 \mathrm{CaCl}_{2}, 17 \mathrm{NaHCO}_{3}, 15$ sodium pyruvate, 5 sodium acetate, 0.02 atenolol) at $35{ }^{\circ} \mathrm{C}$ with cardioplegic 2,3-butanedione monoxime (BDM, $3 \%$ ) and
$5 \%$ Newborn Calf Serum. Atenolol was used to prevent $\beta$-adrenergic mediated effects. The solutions were in equilibrium with $95 \% \mathrm{O}_{2}$ and $5 \% \mathrm{CO}_{2}$, to obtain a $\mathrm{pH}$ between 7.38-7.42.

The time from thoracotomy to dissection was $\sim 3$ min. The right ventricle was opened and papillary muscles were isolated by first dividing the chordae tendinae at the muscle tip and then freeing the muscle base and a small amount of surrounding myocardium from the ventricular wall. Only long, thin, uniformly cylindrical muscles were used.

After dissection, papillary muscles $(\mathrm{n}=52$, length: $4.6 \pm 0.2 \mathrm{~mm}$, weight: $3.5 \pm 0.2 \mathrm{mg}$, preload: $4.0 \pm 0.2 \mathrm{mN}$ ) were mounted vertically in a $10 \mathrm{ml}$ plexi glass organ bath containing the aforementioned $\mathrm{KR}$ solution at $35{ }^{\circ} \mathrm{C}$. The lower muscular end was fixed in a phosphorbronze clip, and the upper tendinous end was attached to an electromagnetic length-tension transducer (University of Antwerp, Belgium).

Preload was initially estimated according to muscle dimensions. After $10 \mathrm{~min}$, muscles were stimulated at interstimulus interval of $1670 \mathrm{~ms}$ and voltage of $10 \%$ above threshold by rectangular pulses of $5 \mathrm{~ms}$ duration through two platinum electrodes. Twenty minutes later, bathing solutions were replaced by corresponding $\mathrm{KR}$ solutions without $\mathrm{BDM}$ and the muscle started to contract. One hour later, bathing solution was replaced by corresponding serum-free KR solution. During the next two hours, the muscles were stabilized. Finally, the muscles were stretched to a muscle length at which active force development was maximal. This length (mm) is known as maximum physiological length $\left(L_{\max }\right)$. Protocols were initiated after obtaining two similar isotonic and isometric control twitches separated by a $10 \mathrm{~min}$ interval.

At the end of the experiment the muscles were lightly blotted and then weighed. Muscle cross-sectional area was calculated by dividing the weight of the muscle by its length at $L_{\max }$. A cylindrical shape and a specific gravity of 1.0 were assumed. Muscle tension was then expressed as force normalized per cross-sectional area (mN.mm ${ }^{-2}$ ).

\section{Experimental protocols}

The effects of increasing concentrations of hU-II $\left(10^{-8}, 10^{-7}\right.$ and $\left.10^{-6} \mathrm{M}\right)$ on contraction, relaxation, and diastolic properties of the myocardium were studied in rabbit papillary muscles in the absence $(n=12)$ or in the presence of (i) losartan $\left(10^{-6} \mathrm{M}, \mathrm{n}=8\right)$, a selective $\mathrm{AT}_{1}$ 
receptor competitive antagonist, (ii) PD-145065 $\left(\mathrm{C}_{52} \mathrm{H}_{65} \mathrm{~N}_{7} \mathrm{O}_{10}, 10^{-7} \mathrm{M}, \mathrm{n}=7\right)$, a nonselective antagonist of ET-1 receptors, (iii) losartan $\left(10^{-6} \mathrm{M}\right)$ plus PD-145065 $\left(10^{-7} \mathrm{M}\right)(\mathrm{n}=8)$, (iv) AngII $\left(10^{-5} \mathrm{M}, \mathrm{n}=10\right)$, or (v) ET-1 $\left(10^{-8} \mathrm{M}, \mathrm{n}=7\right)$. These substances were dissolved in the KR solution before the addition of U-II, and muscle twitches were recorded after a stable response was obtained, typically 15-20 min later. After that, U-II was added cumulatively without any washout between.

Of note, that in each experimental protocol all papillary muscles were obtained from different animals. PD-145065 and hU-II were obtained from American Peptide Company (Sunnyvale, CA, USA) and Bachem (Bubendorf, Switzerland), respectively. All the other reagents were obtained from Sigma (St. Louis, MO, USA). Peptides were prepared in aliquots and stored at $-20{ }^{\circ} \mathrm{C}$.

\section{Data acquisition and analysis}

Isotonic and isometric twitches were converted online to digital data with a sampling frequency of 1000 $\mathrm{Hz}$ (Daqbook/120, IOTech Inc. Cleveland, OH, USA) and analyzed with a dedicated software (University of Antwerp, Belgium).

Selected parameters included: resting tension $\left(\mathrm{RT}, \mathrm{mN} \cdot \mathrm{mm}^{-2}\right.$ ), active tension (AT, $\mathrm{mN} \cdot \mathrm{mm}^{-2}$ ), maximal velocities of tension rise $\left(\mathrm{d} T / \mathrm{d} t_{\max }, \mathrm{mN} \cdot \mathrm{mm}^{-2} \cdot \mathrm{s}^{-1}\right)$ and decline $\left(\mathrm{d} T / \mathrm{d} t_{\min }, \mathrm{mN} \cdot \mathrm{mm}^{-2} \cdot \mathrm{s}^{-1}\right)$, peak isotonic shortening (PS, $\% L_{\max }$ ), and maximal velocities of shortening $\left(\mathrm{d} L / \mathrm{d} t_{\max }, L_{\max } \mathrm{s}^{-1}\right)$ and lengthening $\left(\mathrm{d} L / \mathrm{d} t_{\min }, L_{\max } \mathrm{s}^{-1}\right)$.

In the various protocols, results are given as percent change from baseline. For the parameters that are expressed as negative values (e.g. $\mathrm{d} T / \mathrm{d} t_{\min }$ ) such percent change refers to the absolute values. When the pharmacological inhibitors were used, the term baseline refers to the performance in the presence of those inhibitors, before the addition of U-II.

\section{Statistical methods}

Values are presented as means \pm S.E.M. of $n$ experiments. Effects of increasing concentrations of U-II alone on the different experimental parameters were analyzed by one-way repeated-measures ANOVA. Effects of increasing concentrations of U-II under various experimental conditions were analyzed with a repeatedmeasures two-way ANOVA. Effects on the various parameters of a single concentration of the antagonists were analyzed with a paired t-test. When significant differences were detected with any of the ANOVA tests, a

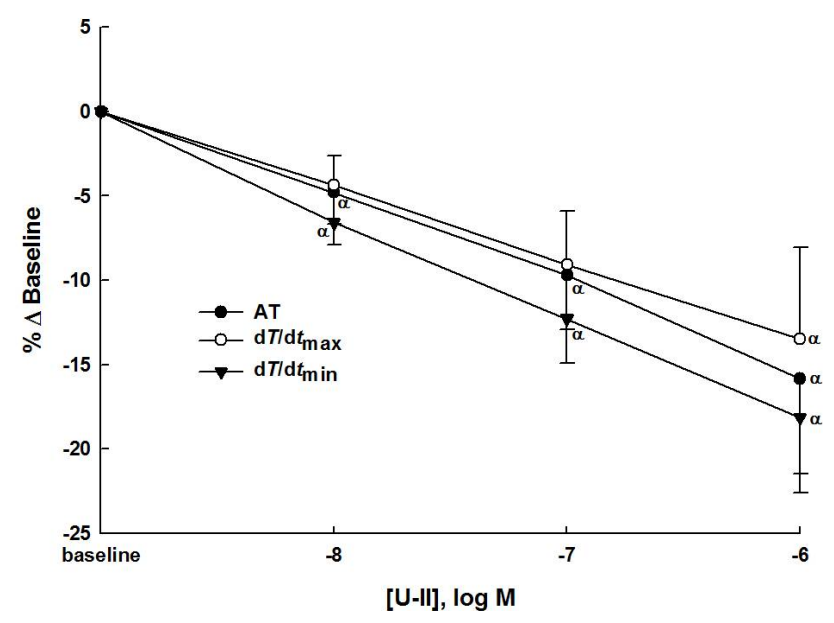

b

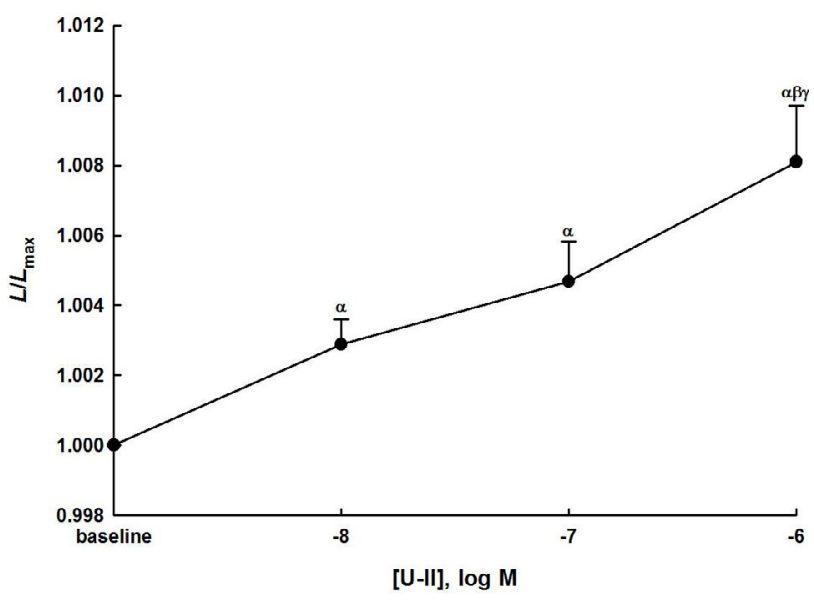

Fig. 1. Effect of increasing concentrations of urotensin II (U-II, $10^{-8}$ to $10^{-6} \mathrm{M}$ ) on active tension (AT), peak rates of tension rise and decline ( $\mathrm{d} T / \mathrm{d} t_{\max }$ and $\mathrm{d} T / \mathrm{d} t_{\min }$, respectively) (top) and muscle length $\left(L / L_{\max }\right.$, bottom). Data are means \pm SEM, expressed as percent variation from baseline. $P<0.05$ : a vs baseline, $\beta$ vs $10^{8} \mathrm{M} \mathrm{U}$-II, Y vs $10^{-7} \mathrm{M}$ U-II.

the Student-Newman-Keuls test was selected to perform pairwise multiple comparisons. $\mathrm{P}<0.05$ was accepted as significant.

\section{Results}

Baseline performance of rabbit papillary muscles was similar in all experimental protocols. Mean values of the contractile parameters from the 52 papillary muscles were as follows: AT $26.0 \pm 1.9 \mathrm{mN} . \mathrm{mm}^{-2}, \mathrm{~d} T / \mathrm{d} t_{\max } 190.4 \pm$ $15.6 \mathrm{mN} \cdot \mathrm{mm}^{-2} \cdot \mathrm{s}^{-1}, \mathrm{~d} T / \mathrm{d} t_{\min } \quad-140.3 \pm 8.6 \mathrm{mN} \cdot \mathrm{mm}^{-2} \cdot \mathrm{s}^{-1}$, PS $15.3 \pm 0.9 \%$ of $\mathrm{L}_{\max }, \mathrm{d} L / \mathrm{d} t_{\max } \quad 1.17 \pm 0.07 \quad \mathrm{~L}_{\max } \cdot \mathrm{s}^{-1}$, $\mathrm{d} L / \mathrm{d} t_{\min }-4.9 \pm 0.4 \mathrm{~L}_{\max } \cdot \mathrm{s}^{-1}$. The presence of losartan, PD-145065, or losartan plus PD-145065 did not significantly modify per se any of the analyzed contractile parameters. The presence of AngII and ET-1 
a

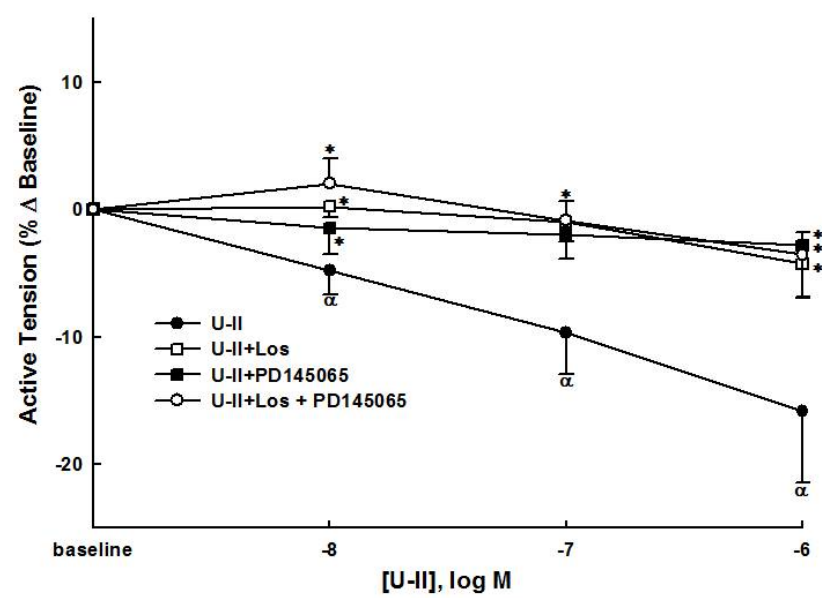

b

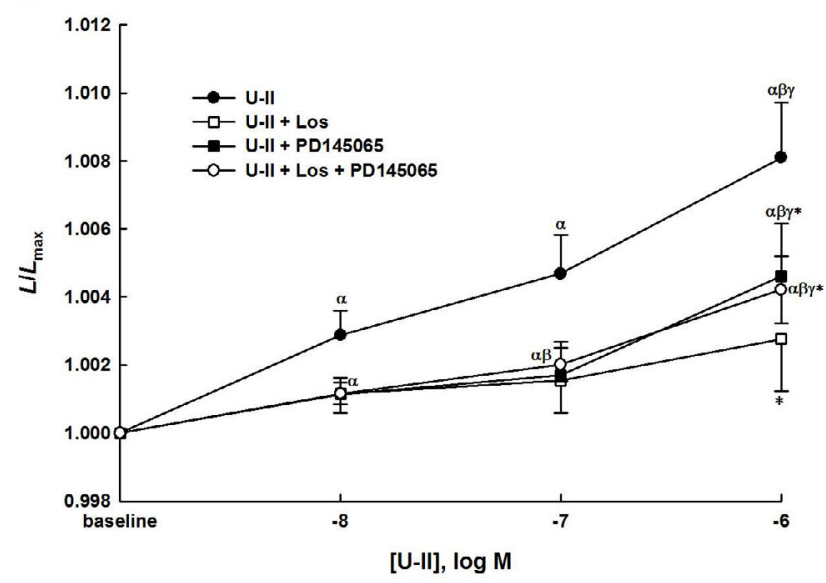

Fig. 2. Effect of increasing concentrations of urotensin II (U-II, $10^{-8}$ to $10^{-6} \mathrm{M}$ ) on active tension (top) and muscle length (bottom, $L / L_{\max }$ ) in the absence (U-II) or presence of a selective $A T_{1}$ receptor antagonist (losartan) (LoS, $10^{-6} \mathrm{M}$ ), a nonselective antagonist of ET-1 receptors (PD145065, $10^{-7} \mathrm{M}$ ), or losartan (Los, $10^{-6} \mathrm{M}$ ) plus PD-145065 $\left(10^{-7} \mathrm{M}\right)$. Data are means \pm SEM, expressed as percent variation from baseline. $P<0.05$ : a vs baseline, $\beta$ vs $10^{-8} \mathrm{M}$ U-II, Y vs $10^{-7} \mathrm{M} \mathrm{U}$-II, * vs U-II alone.

significantly increased active tension by $7.2 \pm 2.1 \%$ and $31.7 \pm 4.9 \%$, respectively.

U-II induced concentration-dependent negative inotropic (AT, $\left.\mathrm{d} T / \mathrm{d} t_{\max }\right)$ and lusitropic $\left(\mathrm{d} T / \mathrm{d} t_{\min }\right)$ effects (Fig. 1). The highest concentration of U-II $\left(10^{-6} \mathrm{M}\right)$ decreased $15.8 \pm 5.6 \%$ AT, $13.5 \pm 5.4 \% \mathrm{~d} T / \mathrm{d} t_{\max }$, and $18.1 \pm 4.5 \% \mathrm{~d} T / \mathrm{d} t_{\text {min }}$. With regard to the diastolic properties of the myocardium, we observed that U-II progressively increased resting muscle length (Fig. 1) at a constant resting tension. Correcting, at the end of the experiment, muscle length to its initial value resulted in a $19.5 \pm 3.5 \%$ decrease of resting tension, without altering the other contractile parameters. These effects indicate an increase in muscle distensibility, or on the other hand, a decrease in muscle stiffness. a

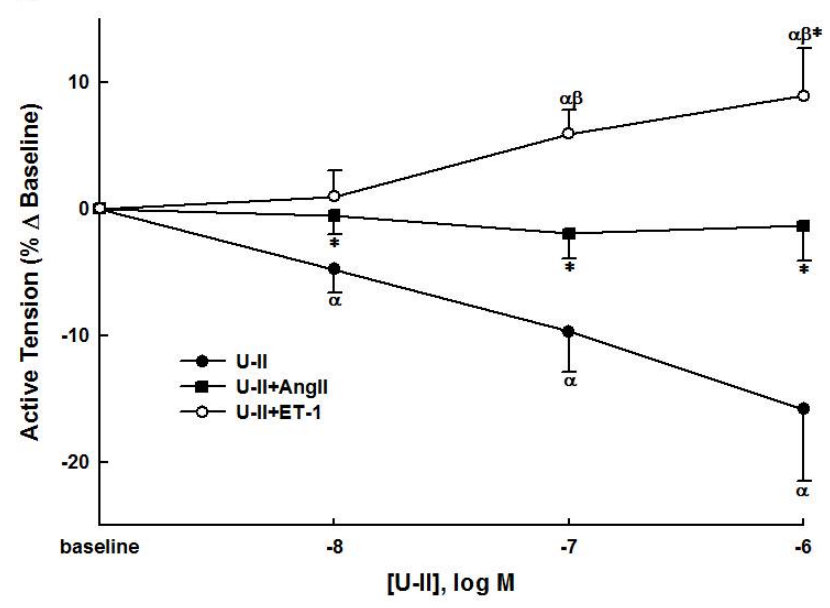

b

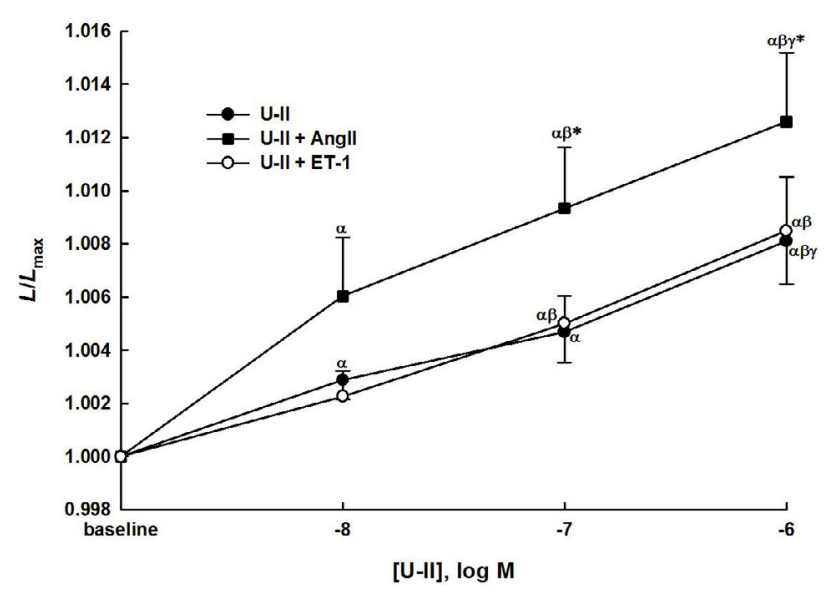

Fig. 3. Effect of increasing concentrations of urotensin II (U-II, $10^{-8}$ to $10^{-6} \mathrm{M}$ ) on active tension (top) and muscle length (bottom, $L / L_{\max }$ ) in the absence (U-II) or presence of angiotensin II (AngII, $\left.10^{-5} \mathrm{M}\right)$, or endothelin $1\left(\mathrm{ET}-1,10^{-8} \mathrm{M}\right)$. Data are means $\pm \mathrm{SEM}$, expressed as percent variation from baseline. $P<0.05$ : a vs baseline, $\beta$ vs $10^{-8} \mathrm{M}$ U-II, Y vs $10^{-7} \mathrm{M} \mathrm{U}$-II, * vs U-II alone.

In the presence of a nonselective endothelin $\mathrm{ET}_{\mathrm{A}} / \mathrm{ET}_{\mathrm{B}}$ receptor antagonist (PD-145065), the negative inotropic (Fig. 2) and lusitropic effects of U-II were abolished. Similarly, losartan, a selective competitive AT1 receptor antagonist, or losartan plus PD-145065 completely abolished the negative inotropic (Fig. 2) and lusitropic effects of U-II. When added previously to the bath, AngII abolished the negative inotropic (Fig. 3) and lusitropic effects of U-II. In the presence of ET-1, U-II promoted a slightly positive inotropic (Fig. 3) and lusitropic effects.

The effects of U-II on myocardial distensibility were significantly attenuated by PD-145065 or PD-145065 plus losartan, leading to a decrease in passive tension of only $11.6 \pm 2.7 \%$ and $9.9 \pm 3.5 \%$, respectively (Fig. 2). On the other hand, in the presence of losartan the 
effects of U-II on passive muscle length and RT were no more statistically significant (Fig. 2). Finally, this effect was increased in the presence of AngII, when resting tension decreased by $27.5 \pm 3.9 \%$, but was unaffected by the presence of ET-1 (Fig. 3).

\section{Discussion}

In the present study we evaluated the myocardial effects of U-II in rabbit papillary muscles. We demonstrated that U-II induced negative inotropic and lusitropic effects, as previously documented (FontesSousa et al. 2007) and a significant concentrationdependent acute increase of myocardial distensibility, or conversely, a decrease in myocardial stiffness. In the presence of a selective $\mathrm{AT}_{1}$ receptor antagonist (losartan), a nonselective antagonist of ET-1 receptors (PD-145065), or both, the negative inotropic effect of U-II (AT, $\left.\mathrm{d} T / \mathrm{d} t_{\max }\right)$ was completely abolished. The same occurred in the presence of AngII, while U-II with ET-1 promoted a slightly positive inotropic effect. On the other hand, the effect of U-II on myocardial distensibility was dependent on $\mathrm{AT}_{1}$ receptors, $\mathrm{ET}_{\mathrm{A}}$ and $\mathrm{ET}_{\mathrm{B}}$ receptors. Additionally, the presence of AngII potentiated this effect.

The concentrations of U-II evaluated in the present study $\left(10^{-8} \mathrm{M}-10^{-6} \mathrm{M}\right)$ were considerably higher than those observed in plasma of control subjects in vivo (average from 2-20 pmol/1) (Ng et al. 2002, Watanabe et al. 2006). These plasma concentrations are increased in several cardiovascular conditions such as hypertension (Cheung et al. 2004), atherosclerosis (Suguro et al. 2007), coronary artery disease (Heringlake et al. 2004), and congestive heart failure (Richards et al. 2002). However, it is important to refer that reported human plasma U-II levels vary by $\sim 1000$ - to 10,000 -fold between groups/assays, which has been ascribed mainly to the methodology chosen to measure the plasma levels of U-II. Furthermore, as U-II might act predominantly in an autocrine/paracrine way, local concentrations are presumably several times higher than those present in the plasma.

The role of U-II in cardiovascular physiology and pathology remains largely uncertain. Recent experimental and clinical studies have revealed increased expression of U-II and UT receptor in animals with experimentally induced heart failure and myocardial infarction and in patients with heart failure, hypertension, atherosclerosis, and diabetic nephropathy, suggesting a potential role of U-II in both cardiovascular and renal diseases (Zhu et al. 2006). On the other hand, the expression of numerous neurohumoral factors such as AngII (Pfeffer and Braunwald 1990), ET-1 (Best and Lerman 2000), catecholamines (Ueyama et al. 2003), thromboxane $\mathrm{A}_{2}$ (Miyahara et al. 1997), and serotonin (Levy 2006) has been shown to be up-regulated in cardiovascular diseases. These studies give rise to the hypothesis that the interaction between U-II and other vasoactive substances may be crucial in modulating the cardiovascular effects of U-II under a certain disease status. Crosstalk of intracellular signaling pathways is probably the underlying mechanism of the interaction between U-II and other vasoactive substances (Zhu et al. 2006).

Both ET-1 and AngII receptor systems are coupled to phospholipase $\mathrm{C} / \mathrm{G}_{\alpha \mathrm{q}}$ protein signaling pathways, resulting in the activation of protein kinase $\mathrm{C}$ isoforms and inositol phosphates, and both systems induce pathological hypertrophy accompanied by contractile dysfunction and poor clinical outcomes (Braunwald and Bristow 2000). U-II shares similar biological activities and signaling pathways with these hypertrophic $\mathrm{G}_{\mathrm{q}}$-coupled receptor ligands, since it has also been observed the coupling of its receptor to activated protein kinase C-dependent pathways (Saetrum Opgaard et al. 2000, Russell and Molenaar 2004).

The decrease of passive tension as the one promoted by U-II represents a potentially important adaptation mechanism, since it demonstrates that U-II might allow the ventricle to reach the same diastolic volume with almost $20 \%$ lower filling pressures (FontesSousa et al. 2007). However, we must consider that a sustained increase in myocardial length, as the one induced by U-II, might contribute to ventricular dilatation, which is another important feature of ventricular remodeling. The acute beneficial effects of U-II on diastolic function may be also overcome by its role in the promotion of cardiac fibrosis and hypertrophy (Bousette et al. 2006b).

The present study showed that the increase of myocardial distensibility induced by U-II is dependent on Ang II and ET-1 systems. The results of the present study are in line with those of previous studies: the presence of losartan (a selective $\mathrm{AT}_{1}$ receptor competitive antagonist) or AngII, respectively abolished and potentiated the effects of U-II on myocardial distensibility. In fact, we have recently shown that the decrease of myocardial stiffness induced by AngII requires $\mathrm{AT}_{1}$ receptor activation (Leite-Moreira et al. 2006). On the other hand, 
although ET-1 also increases myocardial distensibility (Leite-Moreira et al. 2003), there are important differences between the effects of U-II and AngII from those of ET-1. In fact, increased myocardial distensibility in response to ET-1 was observed only in acutely loaded cardiac muscles, which could justify why the effect of UII was maintained in the presence of ET-1.

The development of inhibitors of these neurohumoral systems has proven to be favorable in treating many cardiac diseases by inhibiting or reversing cardiovascular remodeling. Drugs like angiotensin converting enzyme inhibitors, angiotensin receptor blockers, and aldosterone antagonists have been demonstrated to reduce mortality and morbidity in patients (Sleight 2002, Dimopoulos et al. 2004). Additionally, recent studies demonstrated, in a rat model of coronary artery ligation, that SB-611812, a specific UT receptor antagonist, significantly improved cardiac dysfunction (Bousette et al. 2006a) and promoted a reduction of cardiac remodeling (Bousette et al. 2006b).

It is therefore reasonable to hypothesize that some cardiovascular effects could result from the interaction between different neurohumoral systems. From a pathophysiological and clinical point of view, these results are potentially relevant, since the inhibition of a given neurohumoral system might also modulate the effects resulting from the activation of other systems. However, from the data presented, we cannot deduce the specific signaling pathways that underlie these results. Further investigations are needed to clarify this issue.

Additionally, other limitations of this study must be pointed out. We cannot exclude the possibility that UII exerts its effects through activation of AngII or ET-1 receptors, or that both losartan and PD-145065 compound inhibit UT receptor. Therefore, both hypotheses would be a possible explanation for the results. Finally, when we added each or both of the antagonists of AngII or ET-1 systems, there is no direct evidence for the presence of AngII and ET-1 and activation of their respective receptors in the experimental preparation.

In conclusion, the results of the present study suggested that in the rabbit the acute decrease of myocardial stiffness induced by U-II is mediated by AngII and ET-1 systems. These results may contribute to a more complete understanding of the role of U-II in the acute modulation of myocardial function. They also show that neurohumoral systems might have potential points of interaction. Furthermore, this might add to our understanding of the pharmacologic effects of the receptor antagonists of these peptides.

\section{Conflict of Interest}

There is no conflict of interest.

\section{Acknowledgements}

Supported by the Portuguese Foundation for Science and Technology (grant nr. POCI/SAU-FCT/60803/2004, partially funded by FEDER) through the Cardiovascular R\&D Unit (FCT nr. 51/94). Ana Patrícia Fontes-Sousa and Ana Luísa Pires were supported by grants from the Portuguese Foundation for Science and Technology (nr. SFRH/BD/22590/2005 and nr. SFRH/BD/19544/2004, respectively). The results will be presented in part at the American Heart Association Scientific Sessions 2008. New Orleans, Lousiana: November 8-12, 2008.

\section{References}

AMES RS, SARAU HM, CHAMBERS JK, WILLETTE RN, AIYAR NV, ROMANIC AM, LOUDEN CS, FOLEY JJ, SAUERMELCH CF, COATNEY RW, AO Z, DISA J, HOLMES SD, STADEL JM, MARTIN JD, LIU WS, GLOVER GI, WILSON S, MCNULTY DE, ELLIS CE, ELSHOURBAGY NA, SHABON U, TRILL JJ, HAY DW, OHLSTEIN EH, BERGSMA DJ, DOUGLAS SA: Human urotensin-II is a potent vasoconstrictor and agonist for the orphan receptor GPR14. Nature 401: 282-286, 1999.

BEST PJ, LERMAN A: Endothelin in cardiovascular disease: from atherosclerosis to heart failure. J Cardiovasc Pharmacol 35: S61-S63, 2000.

BOUSETTE N, HU F, OHLSTEIN EH, DHANAK D, DOUGLAS SA, GIAID A: Urotensin-II blockade with SB611812 attenuates cardiac dysfunction in a rat model of coronary artery ligation. J Mol Cell Cardiol 41: 285 295, 2006a.

BOUSETTE N, POTTINGER J, RAMLI W, OHLSTEIN EH, DHANAK D, DOUGLAS SA, GIAID A: Urotensin-II receptor blockade with SB-611812 attenuates cardiac remodeling in experimental ischemic heart disease. Peptides 27: 2919-2926, 2006b. 
BRÁS-SILVA C, MONTEIRO-SOUSA D, DUARTE AJ, GUERRA M, FONTES-SOUSA AP, MOURA C, AREIAS JC, LEITE MOREIRA AF: Nitric oxide and prostaglandins - important players in endothelin-1 induced myocardial distensibility. Physiol Res 57: 165-174, 2008.

BRAUNWALD E, BRISTOW MR: Congestive heart failure: fifty years of progress. Circulation 102 (Suppl IV): 14-23, 2000.

CHEUNG BM, LEUNG R, MAN YB, WONG LY: Plasma concentration of urotensin II is raised in hypertension. J Hypertens 22: 1341-1344, 2004.

COULOUARN Y, LIHRMANN I, JEGOU S, ANOUAR Y, TOSTIVINT H, BEAUVILLAIN JC, CONLON JM, BERN HA, VAUDRY H: Cloning of the cDNA encoding the urotensin II precursor in frog and human reveals intense expression of the urotensin II gene in motoneurons of the spinal cord. Proc Natl Acad Sci USA 95: 15803-15808, 1998.

DIMOPOULOS K, SALUKHE TV, COATS AJ, MAYET J, PIEPOLI M, FRANCIS DP: Meta-analyses of mortality and morbidity effects of an angiotensin receptor blocker in patients with chronic heart failure already receiving an ACE inhibitor (alone or with a beta-blocker). Int J Cardiol 93: 105-111, 2004.

DOUGLAS SA, TAYARA L, OHLSTEIN EH, HALAWA N, GIAID A: Congestive heart failure and expression of myocardial urotensin II. Lancet 359: 1990-1997, 2002.

EGGINGER JG, CAMUS A, CALAS A: Urotensin-II expression in the mouse spinal cord. J Chem Neuroanat 31: 146154, 2006.

FONTES-SOUSA AP, BRÁS-SILVA C, PIRES AL, MONTEIRO-SOUSA D, LEITE-MOREIRA AF: Urotensin II acutely increases myocardial length and distensibility: potential implications for diastolic function and ventricular remodeling. Naunyn-Schmiedebergs Arch Pharmacol 376: 107-115, 2007.

GRUSON D, ROUSSEAU MF, AHN SA, VAN LINDEN F, KETELSLEGERS JM: Circulating urotensin II levels in moderate to severe congestive heart failure: its relations with myocardial function and well established neurohormonal markers. Peptides 27: 1527-1531, 2006.

HERINGLAKE M, KOX T, UZUN O, WILL B, BAHLMANN L, KLAUS S, ELEFTHERIADIS S, ARMBRUSTER FP, FRANZ N, KRAATZ E: The relationship between urotensin II plasma immunoreactivity and left ventricular filling pressures in coronary artery disease. Regul Pept 121: 129-136, 2004.

ITO H: Endothelins and cardiac hypertrophy. Life Sci 61: 585-593, 1997.

JOHNS DG, AO Z, NASELSKY D, HEROLD CL, MANISCALCO K, SAROV-BLAT L, STEPLEWSKI K, AIYAR N, DOUGLAS SA: Urotensin-II-mediated cardiomyocyte hypertrophy: effect of receptor antagonism and role of inflammatory mediators. Naunyn-Schmiedebergs Arch Pharmacol 370: 238-250, 2004.

LEITE-MOREIRA AF, BRÁS-SILVA C, PEDROSA CA, ROCHA-SOUSA AA: ET-1 increases distensibility of acutely loaded myocardium: a novel $\mathrm{ET}_{\mathrm{A}}$ and $\mathrm{Na}^{+} / \mathrm{H}^{+}$exchanger-mediated effect. Am J Physiol 284: H1332H1339, 2003.

LEITE-MOREIRA AF, CASTRO-CHAVES P, PIMENTEL-NUNES P, LIMA-CARNEIRO A, GUERRA MS, SOARES JB, FERREIRA-MARTINS J: Angiotensin II acutely decreases myocardial stiffness: a novel $\mathrm{AT}_{1}$, PKC and $\mathrm{Na}^{+} / \mathrm{H}^{+}$exchanger-mediated effect. Br J Pharmacol 147: 690-697, 2006.

LEVY RJ: Serotonin transporter mechanisms and cardiac disease. Circulation 113: 2-4, 2006.

LI J, WANG J, RUSSELL FD, MOLENAAR P: Activation of calcineurin in human failing heart ventricle by endothelin-1, angiotensin II and urotensin II. Br J Pharmacol 145: 432-440, 2005.

MIYAHARA T, SHIBAMOTO T, WANG HG, KOYAMA S: Role of circulating blood components and thromboxane in anaphylactic vasoconstriction in isolated canine lungs. $J$ Appl Physiol 83: 1508-1516, 1997.

NG LL, LOKE I, O'BRIEN RJ, SQUIRE IB, DAVIES JE: Plasma urotensin in human systolic heart failure. Circulation 106: 2877-2880, 2002.

PFEFFER MA, BRAUNWALD E: Ventricular remodeling after myocardial infarction. Experimental observations and clinical implications. Circulation 81: 1161-1172, 1990.

RICHARDS AM, NICHOLLS MG, LAINCHBURY JG, FISHER S, YANDLE TG: Plasma urotensin II in heart failure. Lancet 360: 545-546, 2002.

RUSSELL FD: Emerging roles of urotensin-II in cardiovascular disease. Pharmacol Ther 103: 223-243, 2004. 
RUSSELL FD, MEYERS D, GALBRAITH AJ, BETT N, TOTH I, KEARNS P, MOLENAAR P: Elevated plasma levels of human urotensin-II immunoreactivity in congestive heart failure. Am J Physiol 285: H1576-H1581, 2003.

RUSSELL FD, MOLENAAR P: Investigation of signaling pathways that mediate the inotropic effect of urotensin-II in human heart. Cardiovasc Res 63: 673-681, 2004.

SAETRUM OPGAARD O, NOTHACKER H, EHLERT FJ, KRAUSE DN: Human urotensin II mediates vasoconstriction via an increase in inositol phosphates. Eur J Pharmacol 406: 265-271, 2000.

SAUZEAU V, LE MELLIONNEC E, BERTOGLIO J, SCALBERT E, PACAUD P, LOIRAND G: Human urotensin II-induced contraction and arterial smooth muscle cell proliferation are mediated by RhoA and Rho-kinase. Circ Res 88: 1102-1104, 2001.

SHI L, DING W, LI D, WANG Z, JIANG H, ZHANG J, TANG C: Proliferation and anti-apoptotic effects of human urotensin II on human endothelial cells. Atherosclerosis 188: 260-264, 2006.

SLEIGHT P: Angiotensin II and trials of cardiovascular outcomes. Am J Cardiol 89: 11A-17A, 2002.

SUGURO T, WATANABE T, BAN Y, KODATE S, MISAKI A, HIRANO T, MIYAZAKI A, ADACHI M: Increased human urotensin II levels are correlated with carotid atherosclerosis in essential hypertension. Am J Hypertens 20: 211-217, 2007.

TASAKI K, HORI M, OZAKI H, KARAKI H, WAKABAYASHI I: Mechanism of human urotensin II-induced contraction in rat aorta. $J$ Pharmacol Sci 94: 376-383, 2004.

TZANIDIS A, HANNAN RD, THOMAS WG, ONAN D, AUTELITANO DJ, SEE F, KELLY DJ, GILBERT RE, KRUM H: Direct actions of urotensin II on the heart: implications for cardiac fibrosis and hypertrophy. Circ Res 93: 246-253, 2003.

UEYAMA T, SENBA E, KASAMATSU K, HANO T, YAMAMOTO K, NISHIO I, TSURUO Y, YOSHIDA K: Molecular mechanism of emotional stress-induced and catecholamine-induced heart attack. J Cardiovasc Pharmacol 41 (Suppl 1): S115-S118, 2003.

WANG YX, DING YJ, ZHU YZ, SHI Y, YAO T, ZHU YC: Role of PKC in the novel synergistic action of urotensin II and angiotensin II and in urotensin II-induced vasoconstriction. Am J Physiol 292: H348-H359, 2007.

WATANABE T, KANOME T, MIYAZAKI A, KATAGIRI T: Human urotensin II as a link between hypertension and coronary artery disease. Hypertens Res 29: 375-387, 2006.

WATANABE T, PAKALA R, KATAGIRI T, BENEDICT CR: Synergistic effect of urotensin II with mildly oxidized LDL on DNA synthesis in vascular smooth muscle cells. Circulation 104: 16-18, 2001a.

WATANABE T, PAKALA R, KATAGIRI T, BENEDICT CR: Synergistic effect of urotensin II with serotonin on vascular smooth muscle cell proliferation. J Hypertens 19: 2191-2196, $2001 \mathrm{~b}$.

WEBER H, WEBB ML, SERAFINO R, TAYLOR DS, MORELAND S, NORMAN J, MOLLOY CJ: Endothelin-1 and angiotensin-II stimulate delayed mitogenesis in cultured rat aortic smooth muscle cells: evidence for common signaling mechanisms. Mol Endocrinol 8: 148-158, 1994.

ZHU YC, ZHU YZ, MOORE PK: The role of urotensin II in cardiovascular and renal physiology and diseases. $B r J$ Pharmacol 148: 884-901, 2006. 